\title{
A Contrastive Study of Metadiscourse Elements in Research Articles Written by Iranian Applied Linguistics and Engineering Writers in English
}

\author{
Ailin Firoozian Pooresfahani \\ Ferdowsi University of Mashhad, Iran \\ Gholam Hassan Khajavy \\ Ferdowsi University of Mashhad, Iran \\ Fateme Vahidnia (Corresponding author) \\ Ferdowsi University of Mashhad, Iran \\ E-mail: Fateme.vahidnia@yahoo.com
}

Received: May 12, 2012

Accepted: June 8, 2012

Online Published: June 8, 2012

doi:10.5430/elr.v1n1p88

URL: http://dx.doi.org/10.5430/elr.v1n1p88

\begin{abstract}
This study seeks to investigate the use of interactive and interactional metadiscoursal features in two disciplines, applied linguistics and engineering. The analysis is based on a corpus of eight research articles from the engineering discipline and eight from applied linguistics. The selected corpus was analyzed through the model suggested by Hyland (2005). Results of the study showed that both disciplines used interactive and interactional features in their research articles. In both groups, writers used an interactive metadiscourse more than an interactional one. Also, there were significant differences on the overall frequency of metadiscourse features as well as on the particular occurrence of some categories in interactive and interactional features.
\end{abstract}

Keywords: Metadiscourse, Engineering, Applied Linguistics, Academic writing, Research articles

\section{Introduction}

Academic writing has lately been taken into consideration by a great number of researchers, with focus on the genre of the research article (RA) which is a growing area that has aroused great interest in the last two decades.

Traditionally it was believed that researchers should be unbiased and have a neutral or impersonal style while reporting their findings in academic writing. Likewise, this belief was prevalent in academic writing. However, this predominant view of academic writing has been criticized by several researchers (like Swales, 1990; Tang \& John, 1999; Hyland, 2001b; Vassileva, 2001; Harwood, 2005). Researchers (Thetela, 1997; Hoey, 2001; Hyland, 2005) claim that interaction in written texts can be managed in the same way as the spoken text, though with different effects due to the different medium. Little by little this view has manifested academic writing as social engagement, comprising interaction between writers and readers. Hence, intellectual and proficient writers are not supposed to write texts to signify an external reality, rather to use language to express themselves and their work, and to acknowledge and negotiate social relations with readers. The writers' ability to control the level of personality in their texts, to assert unanimity with readers, to assess their material, and to acknowledge other views, is now identified as a significant feature of successful academic writing (Hyland, 2004).

Due to this fact, researchers have examined not only the structure of the RA, but have also evaluated some of the lexico-grammatical features of RAs including: tense choice, transitivity structures (Martinez, 2001) and citation practices (Hyland, 1999a) accompanied by the use of metadiscoursal elements from a cross-linguistic/cultural perspective. Furthermore, this context has delved into interdisciplinarity (see e.g., Hyland, 1998a, 1999b, 2000, 2001b; Luuka,1994; Mauranen, 1993; Moreno, 1997, 1998; Mur-Dueăs, 2007; Valero-Garcés, 1996). 
Metadiscourse as a novel field of investigation contributes to establishing and producing influential writing, based on people's norms and expectations. It is a concept based on the belief that writing and speaking are more than the transmission of ideas and designating of ideational meaning. Instead they are regarded as social elements in which writers, readers, speakers and listeners interact with each other to have an impact on the ways different ideas are presented and realized (Hyland and Tse, 2004; Hyland, 2004; Hyland, 2005).

Recently, genre-based representation of metadiscourse has been drawing much attention. Hyland (1998b) emphasizes the independence of metadiscourse as linked to the norms and standards of special cultural and professional communities. Consequently, metadiscourse has been investigated in various genres, e.g., academic research articles (Hyland, 1999c; Dahl, 2004), post-graduate dissertations (Bunton, 1999), casual conversations (Schiffrin, 1980), and school textbooks (Crimsone, 1989). Yet despite the importance of metadiscourse, surprisingly little is known about the ways it is realized in key genres in which L2 writers participate. Therefore, this paper seeks to address this gap and aims at comparing and contrasting Iranian applied linguistics and engineering articles regarding metadiscourse elements.

\section{Literature Review}

Traditionally, metadiscourse features have been divided into textual and interpersonal. However, Hyland $(2004,2005)$ and Hyland and Tse (2004) offered a more potent interpersonal view of metadiscourse: "all metadiscourse is interpersonal in that it takes account of the reader's knowledge, textual experiences, and processing needs [...]'( $p$. 161). Accordingly, they give up the Hallidayan textual and interpersonal levels of discourse and take up Thompson's (2001) explanation of interactive and interactional resources being as two inter-related modes of interaction. In line with this view of metadiscourse, scholars' discourse choices through the text are developed out of the relationship between the author(s) and their peers within a particular discourse community. Therefore, both interactive metadiscourse features (sought to organize the material with regard to the readers' needs and expectations) and interactional metadiscourse features (intended to depict the scholars as authors and to unite writer and reader together) are a reply to the interpersonal element of writing.

\subsection{Metadiscourse models}

Metadiscourse is a kind of category which can be debated in various ways. Besides, Linguistic items such as punctuation and typographic markers (i.e. parentheses and underlying) coupled with spoken messages (like tone of voice and stress) can be used to convey our purpose in oral or written texts. (Hyland, 1999c, 2005). Therefore, numerous metadiscourse taxonomies have been suggested (Crismore, 1989; Vande Kopple, 1985, 2002; Hyland, 2005; Adel, 2006).

Vande Kopple (1985) presented the first model. He introduced two main categories of metadiscourse, i.e. "textual" and "interpersonal". In this vein, textual metadiscourse constituted of four strategies: text connectives, code glosses, illocution markers and narrators, and the interpersonal metadiscourse consists of three strategies: validity markers, attitude markers and commentaries. Vande Kopple's model was specifically prominent due to the fact that it was the first organized and systematic attempt for introducing a taxonomy that led to a great deal of studies and new taxonomies. However, the categories are vague and overlap functionally with each other. As a case in point, not only do citations enhance a position by claiming the support of a credible other (validity markers) but also, they show the source of the information (narrators) (Hyland, 2005).

Crismore et al. (1993) introduced the revised model. In this model, two major categories of textual and interpersonal remained the same, but the subcategories were broke down, separated, and reorganized. Furthermore, they divided the textual metadiscourse into two categories of "textual" and "interpretive" markers in order to separate organizational and evaluative functions. Textual markers consist of features which can help the discourse to be organized, and interpretive markers facilitate readers' interpretation and understanding of the writer's intension and writing strategies (Crismore et al., 1993).

The next model introduced by Hyland (2005), divides into two major categories of "interactive" and "interactional". Thompson and Thetela's conception (1995) is of great worth in construction of this model, however; it has a vast breadth of focus by including stance and engagement markers. The interactive part of metadiscourse is preoccupied with the writer's recognition of his reader, and his attempts to accommodate the readers' interests and needs, and to make the argument acceptable and reasonable for him. On the other hand, the interactional part is concerned with the writer's efforts to make his ideas transparent, and to involve the reader by expecting his problems and responses to the text (Hyland, 2005). Following Thompson and Thetela (1995) and Thompson (2001), Hyland and Tse (2004) make a worthwhile distinction between interactive and interactional metadiscourse. Although both have an 
interpersonal function, the former helps the reader through the text to have better understanding with the help of signposts like transition markers, sequencers, code glosses, frame markers etc. These interactive resources are on par with Halliday's (1994) textual metafunction. Interactional metadiscourse, on the other hand, expresses the opinion of the writers, and their association and interaction with their readers. Hence, interactional resources are more related to Halliday's interpersonal metafunction (Hyland, 2005, p. 44). While interactive metadiscourse "primarily involves the management of information flow" (Hyland, 2005, p. 44), interactional metadiscourse is "more personal'"(Hyland, 2005, p. 44) and engages the reader more explicitly in the text by noticing and evaluating the text material. Consequently, this new model proposes that metadiscourse is engrossed in the socio-rhetorical context in which it occurs, and with regard to this fact, variation in the use of metadiscoursal features has been demonstrated to be strongly dependent on the intensions of writers, the audience orc ommunity, as well as socio-cultural contexts.

It is worth mentioning that the above models follow Halliday's (1994) tripartite conception of metafunctions which makes a distinction between the ideational elements of a text-the ways we encode our experiences of the world-and its textual and interpersonal functions.

\subsection{The Hyland's elements of interpersonal model}

Hyland (2005) has defined metadiscourse as "the cover term for the self-reflective expressions used to negotiate interactional meanings in a text, assisting the writer (or speaker) to express a viewpoint and engage with readers as members of a particular community" (p. 37). As mentioned above, interactive resources enable the writer to establish his or her preferred interpretations clearly. They deal with ways of organizing discourse to predict readers' knowledge and manifest the writer's evaluation and consideration of what needs to be made explicit to restrict and guide what can be retrieved from the text (Hyland, 2004). These resources are:

_ Transitions which comprise a range of devices, mainly conjunctions, used to denote additive, contrastive, and consequential steps in the discourse, against to the external world (Hyland, 2004).

- Frame markers refer to text boundaries or elements of schematic text structure, including items used to sequence, to mark text stages, to announce discourse goals, and to show topic shifts (Hyland, 2004).

- Endophoric markers make additional material outstanding and attainable to the reader in recovering the writer's purposes by referring to other parts of the text (Hyland, 2004).

Evidences reveal the source of textual information which derives from outside the current text (Hyland, 2004).

_ Code glosses indicate the restatement of ideational information (Hyland, 2004).

Interactional resources concentrate on the participants in the interaction and try to depict the writer's personality and a tenor which are in agreement with the norms of the disciplinary community. Metadiscourse here considers the writer's efforts to control the level of personality in a text and establish a suitable relationship to his or her data, arguments, and audience, marking the degree of intimacy, the expression of attitude, the communication of commitment, and the extent of reader involvement (Hyland, 2004). These resources are divided into five categories including:

_ Hedges depict the writer's unwillingness to describe propositional information categorically (Hyland, 2004).

_ Boosters communicate certainty and underscore the force of propositions (Hyland, 2004).

_ Attitude markers show the writer's evaluation of propositional information, expressing surprise obligation, agreement, importance, and so on (Hyland, 2004).

_ Engagement markers explicitly address readers, either by selectively focusing their attention or by including them as participants in the text through second person pronouns, imperatives, question forms and asides (Hyland, 2001a).

_ Self-mentions propose the extent of author presence and attendance in terms of first person pronouns and possessives (Hyland, 2004).

\subsection{Metadiscourse Investigations}

Investigations into the written academic genres have proved that different languages and disciplines utilize specific writing norms to make themselves realized. In this line of inquiry, metadiscourse in academic genre has received considerable attention as a major rhetorical aspect which can influence the communicative ability of those concerned. Owing to the idiosyncrasy of the metadiscursive elements, some studies have examined it in different disciplines and languages, e.g., Finish-English economic texts (Mauranan, 1993), Spanish-English economic texts (Valero, 1996), a comparison of linguistics and medicine abstracts (Melander et al., 1997) and medicine, economics and linguistics in 
English, French and Norwegian (Breivega et al, 2002). A few of these studies on metadiscourse in different disciplines and languages are as follows:

As a case in point, Hyland (1999c) examined the use of metadiscourse in two corpora-textbooks and research articles in three disciplines-Biology, Applied Linguistics and Marketing. Analysis of data revealed that more evidences and relational markers were employed in applied linguistics texts; the biology writers preferred hedges; and marketing textbooks comprised fewer evidences and endophorics. Hyland indicated that the greatest diversity in most types of metadiscourse both across genres and disciplines, is found in biology. His research also revealed consistency over genres in marketing and applied linguistics texts and both texts involved significant differences in hedges and connectives. He also realized considerable genre disparities in the use of evidences and person markers in marketing, and endophorics and relation markers in applied linguistics. As a whole, genre differences were more than disciplinary ones, and the textbooks showed greater disciplinary diversity than the research articles.

Similarly, Dahl (2004) explored two kinds of metadiscourse (locational and rhetorical metatext) in three fields (Linguistics, Economics and Medicine) within three languages (English, Norwegian and French). She maintained that 'economics displayed a somewhat higher frequency of the two types than did linguistics for both English and Norwegian, while for French there was hardly any difference within these two disciplines; for all three languages medicine used far less metatext than the other two disciplines.' (p. 1818). Moreover, medicine had the least degree of metatext and its texts were organized in an extremely structured format: Introduction-Methodology-Results-Discussion (Swales, 1990). She determined that economics and linguistics in English and Norwegian used much more metatext than French and they were very similar in patterns, while all three languages made little use of metatext regarding medicine.

In similar vein, Blagojevic (2004) has examined the use of metadiscourse in academic articles written in English by English and Norwegian native speakers across three disciplines (Sociology, Psychology and Philosophy). Regardless of the languages, Blagojevic perceived that Psychology writers employed elaborate ways to make readers be aware of the following or preceding parts. They also utilized less attitude markers, while philosophy writers applied most of the direct comments. The results of his study also indicated that writing of philosophy authors are loaded with a high degree of diversity, whereas psychology writers used the highest degree of standardization in writing and sociology writers were in the middle of these two.

Hyland and Tse (2004) investigated the use of metadiscourse in postgraduate dissertations in six disciplines: Applied linguistics, Public administration, Business Studies, Computer science, Electric engineering, and Biology. Analysis of the data indicated that the humanities and social science disciplines made more use of metadiscourse than the non-humanities. The project revealed the greater use of metadiscourse in the humanities and more inter-disciplinary balance of interactive metadiscourse but its higher proportion in the science dissertations. Moreover, boosters and engagement markers were almost equally distributed across disciplines, whereas hedges were over twice more frequent and self-mentions were approximately four times more common in the humanities. Furthermore, the humanities used transitions more carefully and the non-humanities especially engineering used more emphatics.

Correspondingly, Zarei and Mansoori (2007) explored the metdiscursive patterns within Persian and English languages in computer engineering and applied linguistics. Their findings indicated that both English and Persian languages underscored text coherence over interpersonal functions of language. Likewise, the results exhibited more presuppositions in Persian texts and as a consequence much of the meaning left to be uncovered by the reader.

In another study, Zarei and Mansoori (2011) investigated the use of metadiscourse in two disciplines (applied linguistics vs. computer engineering) within two languages (Persian and English). Analysis of data showed that the metadiscursive resources used differently both within and between the two languages. The analysis proved that humanities focused on the textuality to the detriment of reader involvement.

In line with the results of these studies, the idea of disciplinary importance of metadiscourse across different languages should be prudently taken into consideration.

\section{Method}

\subsection{Corpus}

The corpus used in this study involved two disciplines (Applied Linguistics and Engineering) written in English. Eight applied linguistics articles and eight engineering ones were selected by means of random sampling. Furthermore, random sampling helped us overcome the problem of idiosyncrasy of writers' styles. 
The articles were selected from famous and recently published journal issues. The researchers did their best to select the articles as diverse an array of subjects as possible to be able to increase the external validity of the results. Moreover, this research paper applied Hyland's model (2005) to investigate metadiscourse markers used in these articles.

\section{Results and Discussion}

The frequency of interactive metadiscoursal features was counted separately for both corpuses (Table 1). As can be seen in Table 1, both applied linguistic and engineering authors use logical markers more than other interactive features. However, when it comes to interactional metadiscourse, there is a difference between the two corpuses in using this category. Applied linguistics authors use more? Attitude markers, and engineering authors use hedges more than other interactional features.

To examine the differences between applied linguistics and engineering corpuses in use of metadiscoursal features, chi-square test was used. Results of the analyses are shown in Table 3.

Overall metadiscourse features are used more frequently in engineering research articles than in research articles in applied linguistics. Also, engineering corpus showed a higher use of both interactive and interactional features than applied linguistics corpus. It suggests that the engineering writer's greater? interaction with the reader than applied linguistics writers especially through hedges and attitude markers. Moreover, engineering writers more heavily guide the reader through the text than applied linguistic writers, especially via logical markers and code glosses.

Both applied linguistics and engineering authors make use of interactive metadiscourse more than interactional metadiscourse. It shows that in both disciplines, authors draw more to features to guide the reader through the text than to features that involve the reader in the text.

Results are discussed for each category in the following.

\subsection{Comparison of Interactive Metadiscourse in applied linguistics and engineering disciplines}

Results of the study showed that there is no significant difference between engineering and applied linguistics authors in use of logical markers. Therefore, writers in both disciplines make explicit the relationship between two independent discourse units almost equally.

There was a statistically significant difference between two groups in use of code glosses $\left(X^{2}=18.62, \mathrm{p}<.001\right)$. Therefore, code glosses are used more frequently by engineering authors than applied linguistic writers. It shows that engineering authors use exemplification and reformulation more than applied linguistics authors to elaborate the propositional meaning.

There was a statistically significant difference between two groups in use of Sequencers $\left(X^{2}=11.63, \mathrm{p}<.001\right)$. Sequencers, together with topicalisers, were the interactive metadiscourse features which were found to be significantly more frequent in applied linguistics than engineering subcorpus. It implies that applied linguistics writers facilitate the readers' decoding process by using elements like first, second, and finally which connect parts of the discourse in a linear, progressive manner to a greater extent than engineering authors.

There was a statistically significant difference between two groups in use of topicalisers $\left(X^{2}=6.25, \mathrm{p}<.05\right)$. As mentioned before, topicalisers are also more frequent in the applied linguistics corpus than in the engineering corpus. Therefore, applied linguistics authors introduce new or related topics into the argumentation or resume them at a later point by means of a sentence-initial topicaliser more frequently than engineering authors.

Endophoric markers are used more frequently by engineering authors than applied linguistics authors $\left(X^{2}=30.00\right.$, $\mathrm{p}<.001$ ). Therefore, engineering authors use anaphoric (to direct the readers' attention to a particular point which has already been discussed) and cataphoric (to direct the readers' attention to a particular point which will be discussed later) references to other parts of the text more than applied linguistics authors.

There was no statistically significant difference between the two groups in use of evidences. Therefore, both groups use the same number of evidential to refer to information from other texts.

\subsection{Comparison of Interactional Metadiscourse in applied linguistics and engineering disciplines}

Results of chi-square test showed that there is a statistically significant difference between applied linguistics and engineering writers in use of hedges $\left(X^{2}=153.33, \mathrm{p}<.001\right)$. The number of hedges in the applied linguistics corpus was less than in the engineering corpus. Hedges are features which limit the writer's commitment to what is stated in a proposition. Therefore, engineering authors are more cautious in expressing new findings by using a greater number of hedges. 
There was a statistically significant difference between two groups in use of boosters $\left(X^{2}=16.91, \mathrm{p}<.001\right)$. Applied linguistics writers use more boosters than engineering authors. Boosters emphasize the author's certainty about their argumentation. Furthermore, this higher occurrence of boosters when taken together with a lower occurrence of hedges in the applied linguistics RAs implies that the arguments and propositions are more assertively made than in the engineering RAs.

The number of attitude markers in the applied linguistics corpus was greater than in the engineering corpus $\left(X^{2}=19.70, \mathrm{p}<.001\right)$. Therefore, applied linguistics writers express their attitudes and affective evaluation of propositions more frequently than engineering writers do. This finding is in agreement with the lower number of hedges and higher number of boosters used by applied linguistics writers.

There was no statistically significant difference between the two groups in use of engagement markers. This indicates that writers in both disciplines explicitly build a relationship with the reader, and involve them in the negotiation of academic knowledge.

Results of chi-square test showed that there is a statistically significant difference between applied linguistics and engineering writers in use of self-mentions $\left(X^{2}=7.86, \mathrm{p}<.05\right)$. Based on this, engineering authors use self-mentions more than applied linguistics authors. Self-mentions show self-references and self-citations. It suggests that engineering writers explicitly give reference to themselves more than applied linguistics authors.

\section{Conclusion}

This study set out to examine the metadiscourse features in Iranian applied linguistics and engineering writers, and to compare these two disciplines in using these features.

Results of the study showed that both disciplines use interactive and interactional features in their research articles. However, in both groups, writers use interactive metadiscourse more than interactional metadiscourse. This is not in line with Hyland's (2005) and Hyland and Tse's (2004) finding in eight disciplines that interactive features are less common than interpersonal features. It suggests that there is a cultural diversity in using these features in and across different disciplines. Therefore, Iranian applied linguistics and engineering writers draw more heavily on features that organize discourse in terms of the authors' evaluation of readers' needs and expectations than on features showing the scholars' position as authors connecting themselves with the readers.

Results of chi-square tests showed that there are significant differences between the two groups in use of different categories of interactive and interactional metadiscourse. Regarding interactive metadiscourse features, the two groups were different in four of the six categories. Engineering writers used more code glosses and endophoric markers, and less sequencers and topicalisers than applied linguistics writers. There was a significant difference between the two groups in use of logical markers and evidential. Regarding interactional metadiscourse features, the two groups were different in four of the five categories. Engineering writers used more hedges and self-mentions, and less attitude markers and boosters than applied linguistics writers.

Results of this study should be examined in light of some limitations. We only used eight articles from each discipline, future research can use a larger corpus for comparing these two disciplines. In this study, we did not examine the differences between various categories within the engineering discipline, therefore, future research can examine the differences between various engineering disciplines. Finally, we only examined Iranian applied linguistics and engineering writers' research articles in these two fields. Hence, generalizability of the findings of this study to other contexts should be considered with care.

\section{References}

Adel, A. (2006). Metadiscourse in L1 and L2 English. Philadelphia: John Benjamins.

Blagojevic S. (2004). Metadiscourse in academic prose: A contrastive study of academic articles written in English by English and Norwegian speakers. Studies about Linguistics, 5, 1-7.

Breivega K., D. Dahl \& K. Flottum. (2002). Traces of self and others in research articles. A comparative pilot study of English, French and Norwegian research articles in medicine, economics and linguistics' International Journal of Applied Linguistics 12(2), 218-239.

Bunton, D. (1999). The use of higher level metatext in PhD theses. English for Specific Purposes, 18, 41-56. http://dx.doi.org/10.1016/S0889-4906(98)00022-2

Crismore, A. (1989). Talking with Readers: Metadiscourse as Rhetorical Act. New York: Peter Lang Publishers. 
Crismore, A., Markkanen R., \& Steffensen, M. (1993). Metadiscourse in persuasive writing: a study of texts written by American and Finnish university students. Written Communication, 10, 39-71. http://dx.doi.org/10.1177/0741088393010001002

Dahl, T. (2004). 'extual metadiscourse in research articles: A marker of national culture or of academic discipline? Journal of Pragmatics 36, 1807-1825. http://dx.doi.org/10.1016/j.pragma.2004.05.004

Halliday, M. (1994). An introduction to functional grammar (2nd ed.). London: Edward Arnold.

Harwood, N. (2005).' We do not seem to have a theory... the theory I present here attempts to fill this gap': Inclusive andexclusive pronouns in academic writing. Applied Linguistics, 26(3), 343-375. http://dx.doi.org/10.1093/applin/ami012

Hoey, M. (2001). Textual interaction: An introduction to written discourse analysis. London: Routledge.

Hyland, K. (1998a). Hedging in scientific research articles. Amsterdam: John Benjamins.

Hyland, K. (1998b). Persuasion and context: The pragmatics of academic metadiscourse. Journal of Pragmatics, 30, 437-455. http://dx.doi.org/10.1016/S0378-2166(98)00009-5

Hyland, K. (1999a). Academic attribution: Citation and the construction of disciplinary knowledge. Applied Linguistics, 20(3), 341-367. http://dx.doi.org/10.1093/applin/20.3.341

Hyland, K. (1999b). Disciplinary discourses: Writer stance in research articles. In C. Candlin \& K. Hyland (Eds.), Writing: Texts, processes and practices (pp. 99-121). London: Longman.

Hyland, K. (1999c). Talking to students: Metadiscourse in introductory course books. English for Specific Purposes, 18(1), 3-26. http://dx.doi.org/10.1016/S0889-4906(97)00025-2

Hyland, K. (2000). Disciplinary discourse: Social interactions in academic writing. London: Longman.

Hyland, K. (2001a). Bringing in the reader: Addressee features in academic articles. Written Communication, 18(4), 549-574. http://dx.doi.org/10.1177/0741088301018004005

Hyland, K. (2001b). Humble servants of the discipline? Self-mention in research articles. English for Specific Purposes, 29(3), 207-226. http://dx.doi.org/10.1016/S0889-4906(00)00012-0

Hyland, K. (2001c). Putting specificity into specific purposes: How far should we go now? Perspectives, 13 (1), $1-21$.

Hyland, K. (2004). Disciplinary interactions: Metadiscourse in L2 postgraduate writing. Journal of Second Language writing, 13, 133-151. http://dx.doi.org/10.1016/j.jslw.2004.02.001

Hyland, K. (2005). Metadiscourse: Exploring Interaction in Writing. London: Continuum.

Hyland, K., Tse, P. (2004). Metadiscourse in academic writing: a reappraisal. Applied Linguistics. 25 (2), 156-177. http://dx.doi.org/10.1093/applin/25.2.156

Luuka, M. R. (1994). Metadiscourse in academic texts. In B. L. Gunnarsson, P. Linell, \& B. Nordberg (Eds.), Text and talk in professional context (pp. 77-88).Uppsala, Sweden: ASLA.

Martinez, I. (2001). Impersonality in the research article as revealed by analysis of contrastive structure. English for Specific Purposes, 20, 227-247. http://dx.doi.org/10.1016/S0889-4906(00)00013-2

Mauranen, A. (1993). Contrastive ESP rhetoric: Metatext in Finnish-English Economics texts. English for Specific Purposes, 12, 3-22. http://dx.doi.org/10.1016/0889-4906(93)90024-I

Melander, B., J. Swales \& K. Fredrickson (1997). Journal abstracts from three academic fields in the United States and Sweden: national or disciplinary proclivities? in Duszak A. (eds.), Culture and styles of academic discourse (pp. 251-272). Berlin/ New York: Mounton de Gruyter. http://dx.doi.org/10.1515/9783110821048.251

Moreno, A. (1997). Genre constraints across languages: Causal metatext in Spanish and English RAs. English for Specific Purposes, 16(3), 161-179. http://dx.doi.org/10.1016/S0889-4906(96)00023-3

Moreno, A. (1998). The explicit signalling of premise-conclusion sequences in research articles: A contrastive framework. Text, 18(4), 545-585. http://dx.doi.org/10.1515/text.1.1998.18.4.545

Mur-Dueâs, M. P. (2007). A contribution to the intercultural analysis of metadiscourse in business management research articles in English and Spanish: A corpus driven approach. Unpublished doctoral dissertation, University of Zaragoza, Zaragoza, Spain. 
Schiffrin, D. (1980). Metatalk: Organizational and evaluative brackets in discourse. Sociological Inquiry, 5, 199-236. http://dx.doi.org/10.1111/j.1475-682X.1980.tb00021.x

Swales, J. (1990). Genre analysis. English in academic and research settings. Cambridge: Cambridge University Press.

Tang, R., \& John, S. (1999). The 'I' in identity: Exploring writer identity in student academic writing through the first person pronoun. English for Specific Purposes, 18, 23-39. http://dx.doi.org/10.1016/S0889-4906(99)00009-5

Thetela, P. (1997). Evaluated entities and parameters of value in academic research articles. English for Specific Purposes, 16(2), 101-118. http://dx.doi.org/10.1016/S0889-4906(96)00022-1

Thompson, G. (2001). Interaction in academic writing: learning to argue with the reader. Applied Linguistics. 22 (1), 58-78. http://dx.doi.org/10.1093/applin/22.1.58

Thompson, G., \& Thetela, P. (1995). The sound of one hand clapping: the managment of interaction in written discourse. Text, 15(1), 103-127. http://dx.doi.org/10.1515/text.1.1995.15.1.103

Valero-Garces, C. (1996). Contrastive ESP rhetoric: Metatext in Spanish-English economics texts. English for Specific Purposes 15(4): 279-294.

Vande Kopple, W. J. (1985). Some explanatory discourse on metadiscourse. College Composition and Communication 36, 82-93. http://dx.doi.org/10.2307/357609

Vande Kopple, W. J. (2002). Metadiscourse, discourse, and issues in composition and rhetoric. In F.Barton \& C.Stygall (eds.), Discourse studies in composition. Cresskill, NJ: Hampton Press. 91-113.

Vassileva, I. (2001). Commitment and detachment in English and Bulgarian academic writing. English for Specific Purposes, 20 (1), 83-102. http://dx.doi.org/10.1016/S0889-4906(99)00029-0

Zarei, G. R. \& S. Mansoori. (2007). Metadiscourse in academic prose: A contrastive analysis of English and Persian research articles. The Asian ESP Journal, 3(2), 24-40.

Zarei, G. R. \& S. Mansoori. (2011). A contrastive study on metadiscourse elements used in humanities vs. non humanities across Persian and English. English Language Teaching, 4(1), 42-50. 
Table 1. Interactive Metadiscourse features

\begin{tabular}{llllllll}
\hline $\begin{array}{l}\text { Interactive } \\
\text { Metadiscourse }\end{array}$ & $\begin{array}{l}\text { Logical } \\
\text { Markers }\end{array}$ & $\begin{array}{l}\text { Code } \\
\text { Glosses }\end{array}$ & Sequencer & Topicalisers & $\begin{array}{l}\text { Endophoric } \\
\text { Markers }\end{array}$ & Evidential & Total \\
\hline $\begin{array}{l}\text { Applied } \\
\text { Linguistics }\end{array}$ & 947 & 717 & 60 & 13 & 146 & 208 & 2091 \\
Engineering & 1029 & 890 & 28 & 3 & 256 & 226 & 2432 \\
\hline
\end{tabular}

Table 2. Interactional metadiscourse features

\begin{tabular}{lllllll}
\hline $\begin{array}{l}\text { Interactional } \\
\text { Metadiscourse }\end{array}$ & Hedges & Boosters & $\begin{array}{l}\text { Attitude } \\
\text { Markers }\end{array}$ & $\begin{array}{l}\text { Engagement } \\
\text { Markers }\end{array}$ & Self-mentions & Total \\
\hline $\begin{array}{l}\text { Applied } \\
\text { Linguistics }\end{array}$ & 121 & 224 & 393 & 140 & 30 & 908 \\
Engineering & 405 & 145 & 278 & 162 & 56 & 1046 \\
\hline
\end{tabular}

Table 3.

\begin{tabular}{lllc}
\hline & $X^{2}$ & $d f$ & $p$ \\
\hline Interactive Metadiscourse & & & n.s. \\
Logical Markers & 2.89 & 1 & .001 \\
Code Glosses & 18.62 & 1 & .001 \\
Sequencer & 11.63 & 1 & .05 \\
Topicalisers & 6.25 & 1 & .001 \\
Endophoric Markers & 30.00 & 1 & n.s. \\
Evidentials & .74 & 1 & .001 \\
Total & 25.51 & 4 & \\
& & & .001 \\
Interactional Metadiscourse & & & .001 \\
Hedges & 153.33 & 1 & .001 \\
Boosters & 16.91 & 1 & .s. \\
Attitude Markers & 19.70 & 1 & .05 \\
Engagement Markers & 2.39 & 1 & .05 \\
Self-mentions & 7.86 & 1 & .001 \\
Total & & & \\
Overall Total & 9.74 & 4 & \\
\hline
\end{tabular}

